Uludag Univ. J. Fac. Vet. Med.

34 (2015), 1,2: 89-93

\title{
Sığırlarda Ayak Hastalıklarının Radyolojik ve Biyomekanik İlişsilendirilmesi: 13 Olguluk Bir Ön Çalışma
}

\author{
Hakan SALCI ${ }^{1}$
}

Geliş Tarihi: 25-11-2015

Kabul Tarihi: 30-12-2015

\begin{abstract}
Özet: Sığırlarda ayak hastalıklarına bağlı çeşitli radyolojik bulgular görülmektedir. Bu ön çalışmanın amacı çeşitli kronik ayak hastalığı bulunan sığırlarda radyolojik bulgular ile ayak hastalığına bağlı şekillenmiş biyomekanik bozukluğun ilişkisini değerlendirmektir. Kronik ayak hastalı̆̆ radyolojik bulgular gözlenmiş Holstein ırkı, 13 adet $(\mathrm{n}=13)$ sığır çalışmanın materyalini oluşturdu. Klinik muayenede tanınan ayak hastalıkları limaks, tendovaginitis, panarisyum, deforme tırnak yapısı, taban ulkusu, ökçe erezyonu, beyaz çizgi hastalığı ve yan duvar ulkusu idi. Olguların lokal lezyonlarının yanında plantaro-dorsal radyografilerinde, ayak kemiğinde üremeler, II. ve III. falanksın aksiyal kısmında osteofitik çıkıntılar, ayak ekleminin etrafinda radyolusent ve radyoopakt alanlar, periostal reaksiyonlar vs. saptandı. Bu radyolojik oluşumların bir kısmı ayak hastalığının meydana getirdiği biyomekanik bozukluk nedenliydi. Sonuç olarak sığırlarda şekillenen ayak hastalıkları ayak biyomekaniği etkilemekte ve radyolojik olarak ayak hastalığına spesifik bulgulara ilaveten biyomekanik bozuklukla ilişkili farklı radyolojik bulgular da gözlenebilmektedir.
\end{abstract}

Anahtar Kelimeler: Ayak Hastalığı, Biyomekanik, Radyoloji, Sığır.

\section{Radiological and Biomechanical Correlation of the Claw Diseases in Cattle: A Preliminary Study with 13 Cases}

\begin{abstract}
A variety of radiological findings are seen in the claw diseases of the cattle. The aim of this preliminary study was to evaluate correlation between the radiological findings and biomechanical disturbance resulted from claw disease in the cattle with different claw disease. Material of the study consisted of $13(n=13)$ Holstein breed cattle presented in different times due to claw disease, which had radiological findings on their radiograms. Diagnosed claw diseases in clinical examination were limax, tendovaginitis, panaritium, deformed hoof, solea ulcer, heel erosion, white line disease and abaxial wall ulcer. Together with the local lesions of the cases, proliferations on the foot bone, osteophytes on the axial part of the II. and III. phalanx bone surface, radiolucent and radiopact areas around the foot joint, periosteal reactions and etc. were determined in plantaro-dorsal radiograms. These some of the radiological aspects due to biomechanical problems originated from the claw diseases. As a conclusion, the claw diseases in cattle can affect the foot biomechanic, and associated different radiological findings stem from the biomechanical disturbance can be seen together with the specific radiological findings of the claw disease.
\end{abstract}

Key Words: Claw Disease, Biomechanic, Radiology, Cattle. 


\section{Giriş}

Sığırlarda reprodüktif sistem ve mastitis sorunlar1 gibi en önemli sorunlardan biri de topallıktır ${ }^{1,6,7,9}$. Topallık fertiliteyi düşürmekte ve ekonomik problemlere yol açmaktadır ${ }^{5-7,9}$. Sığırlarda topallığa neden olan durumlar arasında ağrıya yol açan ayak hastalıkları ve problemleri gelmektedir ${ }^{1,7,9}$. Birçok fiziksel problemde olduğu gibi topallık da erken belirlenmeli ve neden olan hastalığa ilişkin sağaltım protokolü uygulanmalıdır. Erken tanınmış olan ayak hastalıklarına uygulanılan tedavi yönteminden etkili sonuç alınabilmekte ve prognoz daha elverişli olmaktadır ${ }^{1,3,5-7}$.

Sığırların ayağını yere bastığı esnada vücut ağırlığının etkisiyle tırnakta meydana gelen biçimsel değişiklik tırnak biyomekaniği olarak adlandırılır ${ }^{1,3}$. Ayak hastalıklarında kemik ve eklemlere yayılmış patolojilerin değerlendirilmesinde konvansiyonel yardımcı tanı yöntemi radyolojidir $^{5,7}$. Özellikle tabanda lezyon meydana getiren ayak hastaliklarında, ayak kemiğinin radyolojik görüntülenmesi gerekir ${ }^{4,5,7,9}$. Ayak hastalıklarında radyolojik bulguların detayland1rıldığı in-vivo ve in-vitro çalışmalar yapılmıştır ${ }^{1,4-7,9}$. Sunulan bu ön çalışma ile kronik ayak hastalığı bulunan 13 sığırdaki radyolojik bulguların ayak hastalığı ve biyomekanik bozuklukla ilişkilendirilmesi amaçlanmıştır.

\section{Materyal ve Metot}

Çalışmanın materyalini Uludağ Üniversitesi Veteriner Fakültesi Cerrahi Anabilim Dalı Klinikleri'ne kronik ayak hastalığı nedenli farklı zamanlarda getirilmiş ve radyolojik bulgular gözlenmiş Holstein ırkı, 13 adet $(\mathrm{n}=13)$ sığır oluşturdu. Hasta sahiplerinden alınan anamnezde tüm olguların arka ayaklarında ayak problemi olduğu ve topalladığı bildirildi.

Sığırların topallık muayeneleri yapıldıktan sonra topallık belirlenen ayak travayda tespit edildi. Ayağın kaba temizliği (fırça, su ve sıvı sabunla yıkma) sonrası anatomik yapıların klinik muayenesi (inspeksiyon, direkt ve indirekt palpasyon, coriumun etkilendiği lezyon varl1ğında sondalama) gerçekleştirildi. Klinik muayene ile olgulardaki ayak probleminin tanıs1 konuldu ve olgularda plantaro-dorsal ve lateral pozisyonlarda radyografiler alındı.

Radyolojik muayene ile prognoz, ayakları oluşturan yapılardaki (kemik ve yumuşak doku) değişiklikler belirlendi ve bazı olgularda tedavi protokolü seçiminde radyolojik inceleme yönlendirici oldu.
Deforme tırnak yapisı tanınan olgularda tırnak kesimi, ayak hastalığı şekillenmiş olanlarda tırnak kesimi sonrası gerekli cerrahi tedavi prosedürleri uyguland.

\section{Bulgular}

Klinik muayene sonucunda iki olguda bilateral, 1 olguda arka sağ ve yine 1 olguda da arka sol ayakta limaks $(n=4)$ belirlendi. Dört olguda $(n=4)$ bilateral deforme tirnak yapisı (1 burulmuş, 2 sivri ve uzun, 1 yayvan ve geniş tırnak) mevcuttu. İki olguda ( $\mathrm{n}=2)$ lateral tırnaklarda bilateral komplike taban ulkusu görüldü. Üç olguda sol arka ayakta karşılaşılan ayrı patolojiler; tendovaginitis purulenta $(n=1)$, kemik ve tendo yayılımlı panarisyum $(\mathrm{n}=1)$ ve ökçe erezyonu, beyaz çizgi hastalığ 1 ve komplike yan duvar ulkusu (n=1) idi (Tablo 1).

\section{Tablo 1. Hastaların eşkal ve tanınan ayak} problemleri.

Table 1. Signalmen and diagnosed claw diseases of the patients.

\begin{tabular}{|c|c|l|}
\hline $\begin{array}{c}\text { Olgu } \\
\text { no }\end{array}$ & \multicolumn{1}{|c|}{ Eşkal } & \multicolumn{1}{|c|}{ Ayak Problemi } \\
\hline $\mathbf{1}$ & Inek, Holstein, 5 yaş & Bilateral arka ayakta limaks \\
\hline $\mathbf{2}$ & İnek, Holstein, 1,5 yaş & $\begin{array}{l}\text { Sol arka ayak lateral parmakta tendo- } \\
\text { vaginitis purulenta }\end{array}$ \\
\hline $\mathbf{3}$ & İnek, Holstein, 8 yaş & $\begin{array}{l}\text { Sol arka ayak lateral parmakta panaris- } \\
\text { yum (kemik ve tendo yayılımlı) }\end{array}$ \\
\hline $\mathbf{4}$ & İnek, Holstein, 9 yaş & Sol arka ayakta limaks \\
\hline $\mathbf{5}$ & İnek, Holstein, 8 yaş & $\begin{array}{l}\text { Bilateral arka ayaklarda deforme tırnak } \\
\text { yapısı (burulmuş tırnak) }\end{array}$ \\
\hline $\mathbf{6}$ & İnek, Holstein, 6 yaş & $\begin{array}{l}\text { Bilateral arka ayaklarda deforme tırnak } \\
\text { yapısı (sivri ve uzun tırnak) }\end{array}$ \\
\hline $\mathbf{7}$ & İnek, Holstein, 5,5 yaş & $\begin{array}{l}\text { Bilateral arka ayaklarda deforme tırnak } \\
\text { yapısı (yayvan ve geniş tırnak) }\end{array}$ \\
\hline $\mathbf{8}$ & İnek, Holstein, 4 yaş & $\begin{array}{l}\text { Bilateral arka ayaklarda deforme tırnak } \\
\text { yapısı (sivri ve uzun tırnak) }\end{array}$ \\
\hline $\mathbf{9}$ & İnek, Holstein, 5 yaş & $\begin{array}{l}\text { Bilateral arka ayaklarda komplike taban } \\
\text { ulkusu }\end{array}$ \\
\hline $\mathbf{1 0}$ & İnek, Holstein, 4 yaş & $\begin{array}{l}\text { Bilateral arka ayaklarda komplike taban } \\
\text { ulkusu }\end{array}$ \\
\hline $\mathbf{1 1}$ & İnek, Holstein, 3yaş & Sağ arka ayakta limaks \\
\hline $\mathbf{1 2}$ & İnek, Holstein, 3 yaş & Bilateral arka ayaklarda limaks \\
\hline $\mathbf{1 3}$ & İnek, Holstein, 5 yaş & $\begin{array}{l}\text { Sol arka ayak lateral tırnakta ökçe } \\
\text { erezyonu, beyaz çizgi hastalığı ve } \\
\text { komplike yan duvar ulkusu }\end{array}$ \\
\hline
\end{tabular}

Limaks olguların tümünde (olgu 1, 4, 11 ve 12) radyolojik olarak beraberinde görülen ayrık tırnak yapısına bağlı I., II. ve III. falanksın aksiyal kısmında osteofitik üremeler belirlendi (Şekil 1). Olgular operatif olarak rutin teknikle interdigital bölgedeki limaksın eksizyonu yapılarak tedavi edildi.

Burulmuş tırnak yapısı olan olgu 5'de radyolojik olarak lateral parmağın ekseninin değiştiğii, mediale doğru eklemden deviye oldu- 
ğu, III. falanksın aksiyal kısmında osteofitik üremeler ve kemik dokuda opasite artışı dikkati çekti. Diğer üç deforme tırnak yapısı bulunan olguda (olgu 6, 7, ve 8) bilateral III. falanksin ekleme yakın kısımlarında radyoopasite artışı ile birlikte interdigital bölgede aksiyal kemiksel çıkıntılar belirlendi. Bu olgulara şiropodi yapıldı ve tırnaklar normal formuna kavuşturuldu.

Komplike taban ulkusu olan olgu 9'da patoloji proksimal yönde derin dokulara doğru yayılmış ve m. fleksor digitalis profundus tendosunu rupture etmişti. Radyolojik olarak ayak kemiğinde ekleme yakın radyolusent görünümle birlikte kemik opasitesinde üremeler görüldü. II. ve III. falanksın aksiyal kısmında osteofitik çıkıntılar belirlendi. Dorsal fleksiyon da görülen bu olguda tırnak amputasyonu gerçekleştirildi. Olgu 10 'da ise radyolojik olarak III. falanksin radyoopasitesinde artış ve ekleme yakın osteofitik üremeler belirlendi. İnterdigital bölgede III. falankın aksiyal kısmında osteofitik üremeler görüldü. Tedavi olarak lezyon açığa çıkarıldı, ayak pansumana alındı ve sağlam ayağın altına tahta takozdan protez uyguland.

Tendovaginitis prulenta belirlenen olgu 2'de patoloji lateral tırnakta taban ulkusunun komplikasyonuna bağlı şekillenmişti. Dorsal fleksiyonla birlikte aksesor parmaklara doğru yayılmış tendovaginal genişleme belirlendi. Radyolojik olarak fleksor tendo boyunca yumuşak doku opasitesinde artış, tüm lateral parmağın falankslarının etkilendiği enflamatif periostal reaksiyon, interdigital bölgede ve diğer sağlam kemiğe doğru yönelmiş yeni kemik oluşumları görüldü. III. falanksta ayrıca osteolitik alanlar da mevcuttu. Punksiyon ve drenaj yapıld 1 , parmak amputasyonuna karar verildi. Ancak patolojinin uzun tedavi edilecek olmasi hasta sahibine bildirilerek hastanın elden çıkarılması kararlaştırıldı.

Sol arka lateral tırnakta panarisyum bulunan olgu 3'ün radyolojik bulgularında I. falanksa kadar ilerlemis enflamatif bir opasite, interdigital bölgede aksiyal kemik opasitesinde çıkıntılar, II. ve III. falanksta yer yer osteolitik alanlar belirlendi. Parmak amputasyonu önerildi ancak hasta sahibi hayvanını elden çıkaracağını belirterek tedaviyi istemedi.

Sol arka lateral tırnakta ökçe erezyonu, beyaz çizgi hastalığı ve yan duvar ulkusu bulunan olgu 13'ün radyolojik görünümünde III. falanksın plantar kısmında osteofitik üremeler ve interdigital bölgede III. falanksin aksiyal kısımlarında osteofitler tespit edildi (Şekil 2).
Terapödik tırnak kesimi sonrasında lokal antibiyotik uygulanarak ayak pansumana alındı.
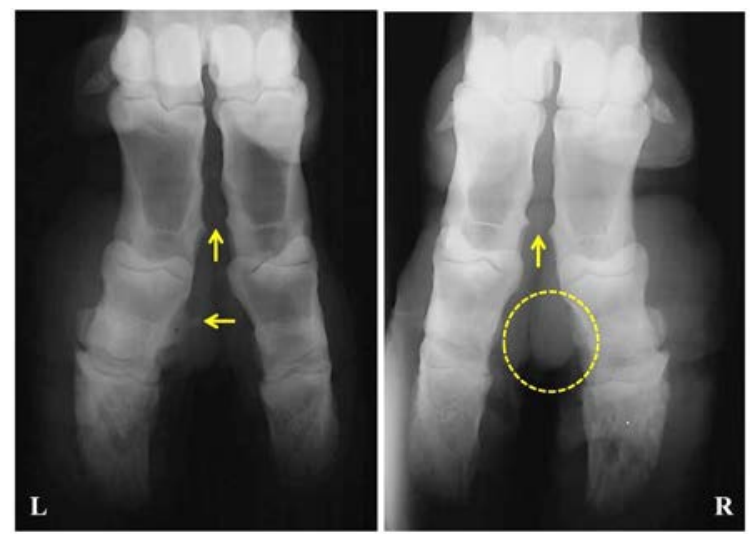

Şekil 1. Olgu 1'e ait radyolojik görüntüler. Sol arka ayak (L) lateral parmağın II. falanksında aksiyal osteofitik üreme (sol ok), bilateral ( $R$ ve L), I. falankslarin aksiyal kisimlarındaki osteofitler (yukarı oklar). Săg arka ayakta interdigital bölgedeki yumuşak doku üremesi (çember).

Figure 1. Radiographic views of the case 1. Axial osteophyte proliferation (left arrow) in the II. phalanx of lateral digit of left hind foot $(L)$, bilateral ( $R$ ve $L$ ) osteophytes in the axial sites of the I. phalanxes (up arrows). Soft tissue proliferation in the interdigital area of the right hind foot (circle).

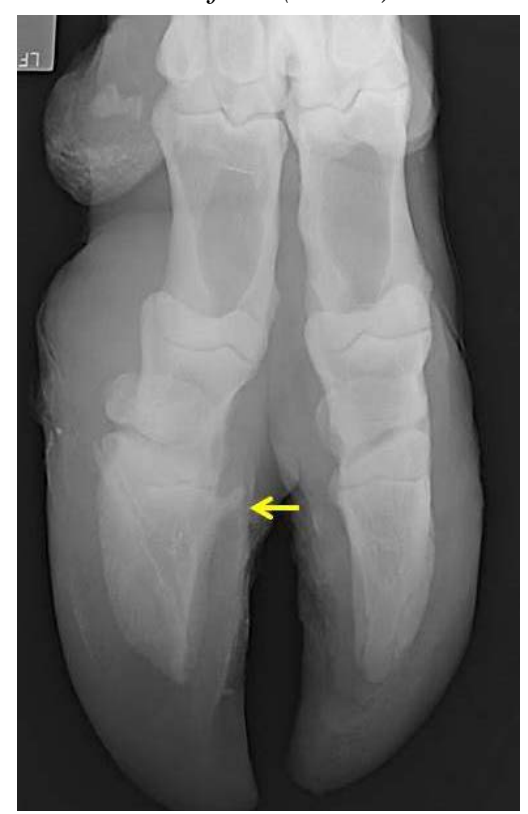

Şekil 2. Olgu 13'e ait radyolojik görüntü. Sol arka lateral parmağın interdigital bölgesinde III. falanksin aksiyal kisımında osteofitik üreme (ok).

Figure 2. Radiographic view of the case 13. In the interdigital area of lateral digit of left hind, osteophyte proliferation on the axial site of the III. phalanx (arrow). 


\section{Tartışma}

Sığırların yürüyüşü esnasında ayağa gelen yükün aktarımına yarım eden organlar taban ve coroner yastık ile ayak kemiğini destekleyici sistemler (interdigital çapraz ligament ve diğer yumuşak yapılar) olarak tanımlanmaktadır ${ }^{1}$. Sığırlarda karşılaşılan birçok ayak hastalığın yardımcı tanısında radyolojik incelemeye gerek duyulur ${ }^{3,5-7,9}$. Ayağın kompleks anatomik yapıya sahip olması nedeniyle, ayak radyografilerini değerlendirmede anatomik bilgi ve deneyime ihtiyaç bulunmaktadır ${ }^{1,6}$. Radyolojik değerlendirmede ayağın yumuşak doku, kemik ve eklem yapıları ayrı ayrı değerlendirilmelidir ${ }^{3-7,9}$. Sunulan bu ön çalışmada 13 olgudaki ayağın biyomekaniğini bozduğu düşünülen ayak hastalık ve problemleri radyolojik bulgularla birlikte yorumlanmıştır.

Sığırlarda arka ayaklarda lateral ön ayaklarda medial tırnaklara daha fazla ağırlık binmektedir ${ }^{1,3}$. Bu nedenledir ki sı ğırlarda birçok ayak hastalığı arka ayaklarda lateral tırnağı etkilemektedir ${ }^{7,8}$. Sunulan çalışmada karşılaşılan ayak problemlerinin tümü arka ayaklarda tespit edildi. Özellikle olgu 2, 3 ve 13'te saptanılan patolojiler arka ayak lateral tırnaklardaydı.

Klinik ve radyolojik muayene öncesinde ayakların interdigital bölgesi de dahil olmak üzere tamamen yıkanması gerekir. Radyolojik muayene amaciyla dorso-palmar/plantar ( $45^{\circ}$ aç111), palmaro/plantaro-dorsal, lateral, lateral oblik ve interdigital pozisyonlarda radyografiler alınır ${ }^{1,3-7}$. Lateral (lateromedial/mediolateral) radyografilerde her iki parmak süperpoze olacağı için bu radyografik pozisyonların alınması önerilmez ${ }^{3}$ ancak kural olarak alınma$1 ı d ı r^{5,7}$. Çalışmadaki olguların tümünde klinik ve radyolojik muayene öncesinde topallık saptanan ayakların yıkanması gerçekleştirildi, radyolojik incelemelerde alınan plantaro-dorsal radyografiler kullanıldı.

Fonksiyonel tırnak kesimi ayaklar ve parmaklar üzerine düșen yükün orantısal olarak dağ 1 lımını sağlar ${ }^{2,8}$. Tırnak kesimi ile tırnak normal anatomik şeklini alarak deforme tırnak yapısı nedenli şekillenebilecek ayak hastalıkları da önlenmiş olur ${ }^{2,7}$. Sunulan olgular içerisinde (olgu 5, 6, 7 ve 8 ) deforme tırnak yapısına bağlı topallık tespit edildi. Radyolojik olarak daha önce belirtildiği gibi lateral parmağın ekseninde değişme ${ }^{5}$, ayak ekleminden mediale deviasyon, III. falanksta osteofitik üremeler ve eklem yüzeyinde opasite artı̧ı ve kemik dokuda opasite artışı dikkat çekti. Ayrıca ayrık tırnak yapısı nedenli limaks tespit edilen olgularda (olgu 1, 4, 11 ve 12) radyolojik olarak III. falanksin aksiyal yüzünde osteofitler belirlendi. Deforme tırnak yapısı görülen ancak klinik ayak hastalığı tespit edilmeyen olgularda karşılaşılan radyolojik bulguların ayağın biyomekaniğinin bozulması nedenli (interdigital çapraz ligament problemi) şekillendiği ve bu nedenle de sekonder olarak limaksın görüldüğü tespit edildi.

Solea ülseri arka ayaklarda lateral tırnaklarda görülmektedir ${ }^{7}$. Özellikle bu tırnakların daha fazla yük taşıması nedeniyle predispoze olduğu bildiriliri, ${ }^{1,7,8}$. Tırnaklarda kronik aşırı uzama ile birlikte erișkin sığırlarda taban yük normal dağılımının bozulması hastalığın ortaya çıkmasına yol açar ${ }^{8}$. Kemik ve eklemi içeren enfeksiyöz ayak problemleri ${ }^{5,7,9}$ ile tabanın etkilendiği parmak ucu ülseri gibi olgularda radyolojik olarak ayak kemiğinde osteolizis odakları saptanmaktadır ${ }^{4,6}$. Çalışmada ayrı ayrı panarisyum, taban ve yan duvar ulkusu gözlenen olgularda (olgu 3, 9, 10 ve 13) hastalığın şiddetine göre benzer radyolojik bulgular (enflamatif görünüm, ayak eklemine yakın kemik üremeleri, II. ve III. falanksın aksiyal kısmında osteofitik çıkıntılar, III. falanksın opasitesinde artış, osteolitik ve osteofitik alanlar gibi) tespit edildi. Her ne kadar bu bulgular komplike ayak hastalığına bağlı şekillense de II. ve III. falanksın aksiyal kısmında şekillenen osteofitik üremelerin ayak kemiğinin destekleyici sistemine (interdigital çapraz ligament) yakın yerlerde meydana gelmesi ayak biyomekaniğine katkı sağlayan bu organların etkilendiğinin belirtisi olarak düşünüldü.

Özellikle proksimaldeki organlara yay1$11 \mathrm{~m}$ gösteren ayak hastalıklarında, yumuşak doku içerisinde abse ve yabancı cisim varlı̆̆ 1 , gaz oluşumu, taban ve ökçenin fistüllü lezyonlar1, falanksların ve susam kemiklerinin kortikal sınırları, kemik yoğunlukları, trabeküler yapılar ile eklem aralık ve yüzeyleri detaylı olarak incelenmelidir ${ }^{1,3,5-7,9}$. Tendovaginitis prulenta belirlenen olgu 2'de klinik olarak dorsal fleksiyon ve tendovaginal genişleme görüldü. Radyolojik olarak yumuşak doku opasitesinde artış, parmağın falankslarının tümünün etkilendiği enflamatif periostal reaksiyon, interdigital bölgede sağlam kemiğe doğru yönelmiş yeni kemik oluşumları ve III. falanksta osteolitik alanlar saptand. $\mathrm{Bu}$ olgudaki problem radyolojik bulgular öncülüğünde geri dönüşsüz olarak değerlendirildi ve 
daha önce rapor edildiği gibi ${ }^{1,3,9}$ radikal bir yaklaşım olan parmak amputasyonu önerildi.

Sığırlarda ayak hastalık ve probleminin tanısına göre tedavi yöntemleri (fonksiyonel ve terapödik tırnak kesimi, lezyonun etrafinın genişletilerek antiseptikli ya da antibiyotikli ayak pansumanı uygulama, antibiyoterapi, sağlam tırnağa protez tahta takoz uygulama ya da cerrahi eksizyon) uygulanmaktadir ${ }^{1,3,6,9}$. Ancak prognozun elverişli olmadığ hastalıklarında gerektiğinde tedavi uygulanmaksızın kesim de önerilebilir ${ }^{4,6,9}$. Sunulan çalışmada fonksiyonel tırnak kesiminin yanında ayak pansumanı ve diğer tedavi prosedürleri uyguland. Tendovaginitisle komplike olan olgu 2 için hasta sahibi tedavi uygulanmasını uygun görmedi.

Sonuç olarak, 13 olguluk bu ön çalışma ile ayak hastalığı nedenli ayak biyomekaniğinin etkilendiği, radyolojik olarak ayak hastalığına spesifik bulgulara ilaveten biyomekanik bozuklukla ilişkili farklı radyolojik bulguların da radyografilerde ortaya çıkabileceği düşünülmelidir.

\section{Kaynaklar}

1. Greenough, P.R., 2007. Bovine Laminitis and Lameness A hands-on approach. Saunders, China.

2. Fjeldaas, T., Sogstad, A.M., Østeras, O., 2006. Claw trimming routines in relation to claw lesi- ons, claw shape and lameness in Norwegian dairy herds housed in tie stalls and free stalls. Prev. Vet. Med., 73: 255-271.

3. İzci, C., 1998. Sığırlarda Ayak Hastalıkları. Selçuk Üniversitesi Veteriner Fakültesi, Konya.

4. Kofler, J., 1999. Clinical study of toe ulcer and necrosis of the apex of the distal phalanx in 53 cattle. Vet. J., 157: 139-147.

5. Meimandi-Parizi, A., Shakeri, M.A., 2007. Abattoir study of radiographic changes of bones and joints of digital region in cattle with abnormal claws. Vet. Arhiv., 77: 187-194.

6. Nouri, M., Vajhi, A., Marjanmehr, S.H., Nowrouzian, I., Faskhoudi, D., 2013. A post-mortem qualitative radiographic study of the foot with special reference to the digital lesions in culling lame cows. Anim. Vet. Sci., 1: 27-31.

7. Nouri, M., Vajhi, A., Nowrouzian, I., Marjanmehr, S.H., Faskhoudi, D., 2008. "Rustelholz" ulcer in culling lame cows: clinical and radiographic interpretation. Iran. J. Vet. Surg. 3: 29-36.

8. Nuss, K., Paulus, N., 2006. Measurements of claw dimensions in cows before and after functional trimming: A post-mortem study. Vet. J., 172: 284-292.

9. Starke, A., Heppelmann, M., Beyerbach, M., Rehage, J., 2007. Septic arthritis of the distal interphalangeal joint in cattle: comparison of digital amputation and joint resection by solar approach. Vet. Surg., 36: 350-359. 
